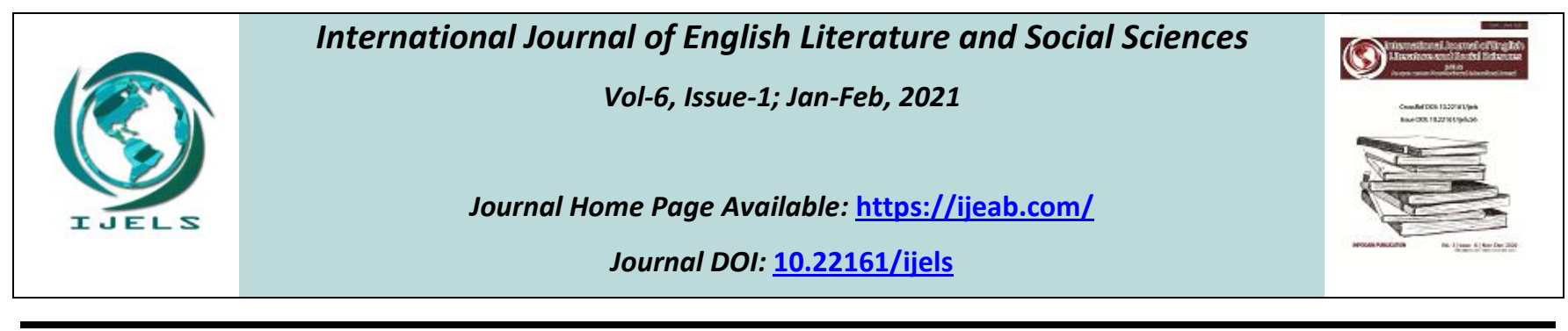

\title{
Analysis of the Factors Influencing the Performance of Crowdsourcing Contractors
}

\author{
Yanjing Xu
}

Department of Information, Central University of Finance and Economics, China

Received: 08 Nov 2020; Received in revised form: 15 Dec 2020; Accepted: 29 Dec 2020; Available online: 07 Jan 2021

(C2021 The Author(s). Published by Infogain Publication. This is an open access article under the CC BY license

(https://creativecommons.org/licenses/by/4.0/).

\begin{abstract}
The key problem in the field of crowdsourcing is the influencing factors of the successful bidder's performance. The existing research on bid winning performance mainly focuses on the performance of the employer in implementing crowdsourcing competition, specifically task performance. The existing researches mainly focus on the task characteristics, scheme characteristics and the characteristics of the contractor to explore the influencing factors of the Contractor's bid winning performance.
\end{abstract}

Keywords-crowdsourcing, influencing factors, receiving party, task performance, winning performance.

\section{INTRODUCTION}

Crowdsourcing competition has gradually developed into a mixed mode, such as the well-known crowdsourcing websites such as zhubajie.com and yipinweike.com. The transaction mode of piecework system is suitable for low innovation and low technology tasks, while the transaction mode of bidding system is suitable for low innovation and high technology tasks; Reward trading mode is suitable for high innovative and low technical tasks; employment trading mode is suitable for high innovative and high-tech tasks (Wu Jun, et al,2015).Different from reward mode and piecework mode, bidding mode and employment mode both select the contractor first, determine the cooperative relationship, and then carry out crowdsourcing tasks. Under the mixed crowdsourcing mode, the recipient may participate in four crowdsourcing modes at the same time. The performance of the target not only directly affects the economic return of the recipient, but also affects the sustainability of their participation in crowdsourcing tasks to a great extent (Bockstedt, et al., 2011). In the mixed crowdsourcing mode, the receiving party needs to set up a personal online shop on the crowdsourcing platform to comprehensively display the personal information profile, historical evaluation, number of skills, cases, credit points and other contents of the receiving party. Before carrying out crowdsourcing activities, the employer will first be noticed by the comprehensive information displayed by the individual shop of the receiving party, forming the first cause effect. However, the existing researches still focus on task performance, and think that factors such as task density, task number, project style, experience and so on affect the work of the contractors, and then affect the possibility of their winning the bid.

\section{CROWDSOURCING COMPETITION}

Crowdsourcing competition refers to a group of seekers using the intelligence of a large number of independent individuals to meet the requirements of a project through cooperation or competition. This project is usually assigned to employees in the organization (Geiger and Schader., 2014). With the development of technology and e-commerce, a third-party platform, known as the intermediate crowdsourcing platform, has been established to match the business needs with the skills of people who 
are usually outside the organization. In a typical crowdsourcing environment, three entities participate: 1) crowd Searcher; 2) platform operator; 3) crowd. The group seeker publishes a project with project demand on the intermediary crowdsourcing platform, gives a fixed reward amount to the project, and selects the best solution. The crowd competes with each other and rewards employees who submit the best solution. The crowdsourcing platform based on competition promotes group competition and finds the best solution for seekers. (Ayaburi, et al,2019)

In 2013, zhubajie.com launched a new crowdsourcing service transaction mode - store transaction mode, providing each service provider with its own store page and personalized decoration tools (Feng Yingchao and Zhou Xiangzhen,2019). Zhubajie.com is China's largest crowdsourcing service trading platform. Its trading volume accounts for more than $80 \%$ of domestic similar markets. It has more than 10 million makers selling services and 3 million entrepreneurs purchasing services. The platform makes users sell services in the form of stores by packaging users into stores. Therefore, users are participants in crowdsourcing services, They are also entrepreneurs who use their own technology and experience to start their own businesses (Gu Shengzhi and Li Rui, 2016). In the crowdsourcing process of reward offering mode in competition market, after the employer publishes problems or tasks on the platform, the reward will be trusteeship. The contractor will search on the platform and submit the scheme. The contractor will determine the winner, and the platform will transfer the reward to the winner. The crowdsourcing process in the employment market is that the employer takes the initiative, selects the subcontractors on the platform, determines the appropriate partners according to the skills of the subcontractors on the platform, and then directly hands over the tasks to the subcontractors, and finally determines the task plan after the communication between the subcontractors and the employer. Therefore, the transaction between the two sides is one-to-one, and the transaction mode is more flexible (Hu Jingsi, 2017). Since then, the mixed crowdsourcing mode of piecework, reward, bidding and store has become popular in China.

\section{ORGANIZATIONAL FRAMEWORK OF CROWDSOURCING}

We conceptualize crowdsourcing (Dwarakanath, et al.2016). Monitoring and evaluating crowd behavior; verifying the identity of users before publishing information on the website or participating in online competitions; deleting false information; screening users may mark suspicious content or false answers.
Our crowdsourcing conceptual model includes the following elements (Fig.1)

(1) Crowdsourcing tasks: crowdsourcing tasks are also known as problems or challenges.

(2) Receiving party: the individual (crowd staff) performing the task. In the context of fraudulent crowdsourcing, crowd related issues involve malicious human behavior and the identification of mechanisms that may trigger such behavior.

(3) Crowdsourcing platform: connecting people and problem owners. In capturing examples of crowdsourcing spoofing, we focus on the risks and vulnerabilities associated with the platform or its management.

(4) Contractee: define tasks, publish tasks on the platform, and provide data and tools for task completion. For our analysis, we focus on information about the risks that are initiated by the employer or caused by their negligence in the context of the problem owner.

(5) Governance/Management: we collect information about the governance mechanisms and related vulnerabilities used in the event, such as the lack of quality control and the use of outlier detection methods.

(6) Group contribution: the output of group members after completing tasks.

\section{A STUDY ON THE PERFORMANCE OF THE CONTRACTOR IN WINNING THE BID}

The existing research on bid winning performance mainly focuses on the performance of the employer in implementing crowdsourcing competition, specifically task performance. On the basis of task performance research, scholars pay more attention to the bid winning performance of contractors as the main participants. The performance of winning a bid directly affects the economic return of the contractor, stimulates its online participation behavior, improves the performance level of crowdsourcing competition, optimizes the crowdsourcing platform environment, and promotes the sound development of crowdsourcing competition (Gefen, 2016). The existing researches mainly focus on the task characteristics, scheme characteristics and the characteristics of the contractor to explore the influencing factors of the contractor's bid winning performance. As shown in TABLE1,2,3.

Based on task characteristics, previous studies have found that task innovation, task risk, task bonus, tacit task, task complexity and other factors affect the possibility of winning the bid. Chi and Ren (2019) found that task innovation has a positive impact on the performance of the 
answers by influencing customer relationship performance. Liu, et al. (2016) pointed out that task risk has a significant negative impact on crowdsourcing performance. Gefen (2016) Martinez and Walton (2014) terwiesch (2008) Chi and Ren (2019) proposed that the task bonus has a positive impact on the Contractor's bid winning performance. Zheng (2011) confirmed that tacit task negatively affects the possibility of winning the contract. Liu(2016) found that task complexity negatively affected crowdsourcing performance.

Based on the characteristics of the project, it has been found that the order of project submission, the creative and thoughtful style, the number of solutions submitted, and the results of the last competition affect the possibility of winning the bid. Bockstedt (2011) found that the lower ranked competitors who submitted materials for the first time in the competition were more likely to succeed. Mahr (2015) found that creative and thoughtful problem-solving styles can effectively promote successful problem solving. Di and Vojnovic (2009) proposed that the number of solutions submitted by Witkey has a significant positive impact on performance. Khasraghi and Aghaie(2014), confirmed that the latest performance of the contestants was positively correlated with their performance.

Based on the characteristics of the contractor, it has been found that the disclosure of the identity of the contractor, skills, experience, competition frequency, competition time and so on have a great impact on the bid winning performance. Patrick, et al. (2018) found that there was an inverted U-shaped relationship between the knowledge distance of the problem seeker and the attention of the problem solver. The disclosure of the seeker's identity of high position enterprises moderated this relationship, and the relationship of high position enterprises was closer than that of low position enterprises. Mo (2018), Huang (2012), Boudreau (2011) put forward the professional skills of the contractor to improve the possibility of winning the bid, such as professional level, professional knowledge, ability, total skill level, etc. Mo (2018) found that the experience of the subcontractors increased their chances of winning the bid. Khasraghi and Aghaie (2014) confirmed that the participation time (time since the last competition) was negatively correlated with the performance; the participation frequency of participants was positively correlated with their performance.

\section{FIGURES AND TABLES}

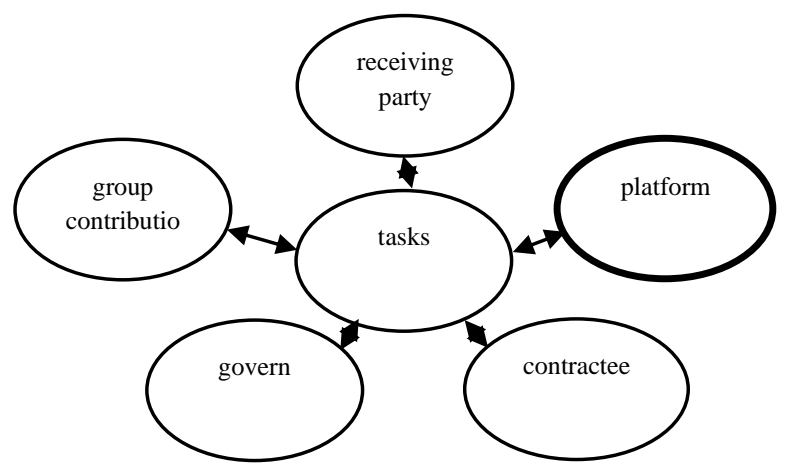

Fig.1: Conceptual framework of crowdsourcing

Table 1: Task characteristics

\begin{tabular}{|c|c|c|}
\hline Dimensions & study found & $\begin{array}{l}\text { Representative } \\
\text { literature }\end{array}$ \\
\hline $\begin{array}{l}\text { Mission } \\
\text { Innovation }\end{array}$ & $\begin{array}{l}\text { Hasa significant } \\
\text { positive impact on } \\
\text { performance of the } \\
\text { respondent. }\end{array}$ & $\begin{array}{l}\text { Chi, A., Ren } \\
\text { N.(2019) }\end{array}$ \\
\hline Mission risk & $\begin{array}{l}\text { has a significant } \\
\text { negative impact on } \\
\text { crowdsourcing } \\
\text { performance. }\end{array}$ & $\begin{array}{l}\text { Liu, S., Xia, F., } \\
\text { Zhang, J., et al. } \\
(2016)\end{array}$ \\
\hline $\begin{array}{l}\text { Mission } \\
\text { bonus }\end{array}$ & $\begin{array}{l}\text { has a positive effect } \\
\text { on performance of } \\
\text { the receiving party }\end{array}$ & $\begin{array}{ll}\text { Gefen } & (2016) \\
\text { Martine } & (2014)\end{array}$ \\
\hline $\begin{array}{l}\text { Mission } \\
\text { acquiescence }\end{array}$ & $\begin{array}{l}\text { has a negative effect } \\
\text { of the possibility of } \\
\text { winning the bid. }\end{array}$ & $\begin{array}{l}\text { Zheng, } \\
(2011)\end{array}$ \\
\hline $\begin{array}{l}\text { Task } \\
\text { Complexity }\end{array}$ & $\begin{array}{l}\text { has a significant } \\
\text { negative impact on } \\
\text { the performance of } \\
\text { crowdsourcing. }\end{array}$ & $\begin{array}{l}\text { Liu, S., Xia, F., } \\
\text { Zhang, J., et al. } \\
(2016)\end{array}$ \\
\hline
\end{tabular}

Table 2: Scheme features

\begin{tabular}{|c|c|c|}
\hline Dimensions & study found & $\begin{array}{l}\text { Representative } \\
\text { literature }\end{array}$ \\
\hline $\begin{array}{l}\text { Creative and } \\
\text { thoughtful } \\
\text { style }\end{array}$ & $\begin{array}{l}\text { Can effectively } \\
\text { promote the } \\
\text { successful solution } \\
\text { of the problem }\end{array}$ & Mahr, D.(2015) \\
\hline $\begin{array}{l}\text { Proposal } \\
\text { submission } \\
\text { sequence }\end{array}$ & $\begin{array}{l}\text { The lower ranking } \\
\text { contestants who } \\
\text { submit materials for } \\
\text { the first time in the } \\
\text { competition are more }\end{array}$ & $\begin{array}{l}\text { Bockstedt, J. } \\
\text { 2011) }\end{array}$ \\
\hline
\end{tabular}




\begin{tabular}{|l|l|l|}
\hline & likely to succeed & \\
\hline $\begin{array}{l}\text { Number of } \\
\text { solutions } \\
\text { submitted }\end{array}$ & $\begin{array}{l}\text { It has a significant } \\
\text { positive impact on } \\
\text { performance }\end{array}$ & $\begin{array}{l}\text { Di, Palantino, } \\
\text { D.Vojnovic, M . } \\
(2009)\end{array}$ \\
\hline
\end{tabular}

Table 3: Characteristics of the contractor

\begin{tabular}{|c|c|c|}
\hline Dimensions & study found & $\begin{array}{l}\text { Representative } \\
\text { literature }\end{array}$ \\
\hline Effort & $\begin{array}{l}\text { The effort of the } \\
\text { solver is positively } \\
\text { correlated with the } \\
\text { performance }\end{array}$ & $\begin{array}{l}\text { Dissanayake,I., } \\
\text { Mehta, N.(2019) }\end{array}$ \\
\hline $\begin{array}{l}\text { Disclosure of } \\
\text { the identity } \\
\text { of job } \\
\text { seekers }\end{array}$ & $\begin{array}{l}\text { There is an inverted } \\
\text { U-shaped } \\
\text { relationship } \\
\text { between the } \\
\text { knowledge distance } \\
\text { of the problem } \\
\text { seeker and the } \\
\text { attention of the } \\
\text { problem solver }\end{array}$ & $\begin{array}{l}\text { Patrick,P., } \\
\text { Lüttgens,Dirk } \\
\text { (2018) }\end{array}$ \\
\hline $\begin{array}{l}\text { Working } \\
\text { situation }\end{array}$ & $\begin{array}{l}\text { The situation of } \\
\text { mobile workers is } \\
\text { positively related to } \\
\text { task performance }\end{array}$ & $\begin{array}{l}\text { Ikeda, K., Hoashi, } \\
\text { K. ( 2017) }\end{array}$ \\
\hline $\begin{array}{l}\text { Service } \\
\text { quality }\end{array}$ & $\begin{array}{l}\text { has a significant } \\
\text { positive impact on } \\
\text { the performance of } \\
\text { the respondents }\end{array}$ & $\begin{array}{l}\text { Chi, A., Ren, N. } \\
(2019)\end{array}$ \\
\hline Self efficacy & $\begin{array}{l}\text { has a positive } \\
\text { impact on the effort } \\
\text { and subsequent } \\
\text { performance in the } \\
\text { competitive } \\
\text { environment }\end{array}$ & $\begin{array}{l}\text { Dissanayake, I., } \\
\text { Mehta, N. et al. } \\
(2019)\end{array}$ \\
\hline $\begin{array}{l}\text { Competition } \\
\text { time }\end{array}$ & $\begin{array}{l}\text { There is a negative } \\
\text { correlation between } \\
\text { time } \\
\text { performance }\end{array}$ & $\begin{array}{ll}\text { Khasraghi, } & \text { H. J., } \\
\text { Aghaie, } & \text { A. } \\
(2014) & \end{array}$ \\
\hline $\begin{array}{l}\text { Participation } \\
\text { frequency }\end{array}$ & $\begin{array}{l}\text { Participants' } \\
\text { participation } \\
\text { frequency is } \\
\text { positively correlated } \\
\text { with their } \\
\text { performance. }\end{array}$ & $\begin{array}{ll}\text { Khasraghi, } & \text { H.J., } \\
\text { Aghaie, } & \text { A. } \\
(2014) & \end{array}$ \\
\hline
\end{tabular}

\section{CONCLUSION}

At present, there are three perspectives on the influencing factors of crowdsourcing performance, one is the task employer, the other is the scheme characteristics, and the third is the characteristics of the contractor. The research on the influencing factors of crowdsourcing performance has limitations. The existing research fails to pay attention to the persuasive effect of trust on the employer beyond the quality of the scheme. Because the construction of trust and its construction mechanism can reduce the uncertainty caused by information asymmetry in the transaction process, so trust theory is very important in the field of crowdsourcing. We apply trust theory to crowdsourcing.

\section{ACKNOWLEDGEMENTS}

An acknowledgement section may be presented after the conclusion, if desired.

\section{REFERENCES}

[1] Wu Jun, Cui Haozhe, Zhao Jiaqi.(2015).Research on the matching of task classification and transaction mode of crowdsourcing platform - Based on the exploration of crowdsourcing websites at home and abroad[J]. Progress and Countermeasures of science and technology,32 (14),pp. 6-11.

[2] Bockstedt, J., Mishra,A. ,Druehl, C.(2011).Doparticipation strategy and experience impact the likelihood of winning in unblind innovation contests?[J]. Available at ssrn, 10,pp. 2139.

[3] Ayaburi,E.W.,Lee,J.,Maasberg,M.(2019).Understandi ng Crowdsourcing Contest Fitness Strategic Decision Factors and Performance: An ExpectationConfirmation Theory Perspective[J]. Information Systems Frontiers.

[4] Feng Yingchao, Zhou Xiangzhen.(2019).Service productization supported by crowdsourcing platform: from the perspective of service ecosystem [J].Business economics research, (16),pp. 86-89.

[5] Gu Shengzhi, Li Rui.(2016). Internet entrepreneurship leads new urbanization [J]. China soft science, (01): 616K. Elissa, "Title of paper if known," unpublished.

[6] $\mathrm{Hu}$ Jingsi.(2017).Research on pricing strategy of crowdsourcing platform based on bilateral market theory [D].

[7] Dwarakanath,A.,Shrikanth,N.C.,Abhinav,K.,Kass,
A.(2016).Trustworthiness
in
Enterprise

Crowdsourcing: a Taxonomy \& evidence from data. ICSE '16 Companion, May 14-22, Austin, TX, USA. 
[8] Gefen, D., Gefen, G., Carmel, E.(2016).How project description length and expected duration affect bidding and project success in crowdsourcing software development[J].Journal of Systems and Software, 116,pp. 75-84.

[9] Chi, A., Ren, N., (2019).Research on the Impact of Task Feedback on the Performance of Creative Crowdsourcing solvers[C] the 2019 10th International Conference.

[10]Liu, S., Xia, F., Zhang, J., et al.(2016). How crowdsourcing risks affect performance: an exploratory model[J]. Management Decision, 54(9),pp. 2235-2255.

[11] Martinez, M.G., Walton,B.,(2015).The wisdom of crowds: the potential of online communities as a tool for data analysis[J]. Technovation, 34(4),pp. 203-214.

[12]Zheng, H., Li, D., Hou,W.,(2011). Task design, motivation, and participation in crowdsourcing contests[J]. International Journal of Electronic Commerce, 15(4),pp. 57-88.

[13] Khasraghi, H.J., Aghaie, A.(2014). Crowdsourcing contests: understandingthe effect of competitors' participation history on their performance[J]. Behaviour \& Information Technology,33(10-12),pp. 1383-1395.

[14] Dissanayake, I., Mehta, N., Palvia, P., et al.(2019). Competition Matters! Self-Efficacy, Effort, and Performance in Crowdsourcing Teams[J]. Information \&Management.

[15] Ikeda, K., Hoashi, K.(2017).Crowdsourcing GO: Effect of Worker Situation on Mobile Crowdsourcing Performance[C].Chi Conference.

[16] Patrick, P., Lüttgens, Dirk, Piller, F. T. (2018).Attracting solutions in crowdsourcing contests: The role of knowledge distance, identity disclosure, and seeker status[J]. Research Policy:S0048733318301872-.

[17] Di,Palantino.D.,Vojnovic,M.(2009).Crowdsourcing and all-pay auctions [C] .Proceedings of the 10th ACM Conference on Electronic commerce.Stanford,7,pp. 6-10.

[18] Mahr, D., Rindfleisch, A., Slotegraaf,R.J.(2015). Enhancing crowdsourcing success: the role of creative and deliberate problem-solving styles[J]. Customer Needs and Solutions, 2(3),pp. 209-221. 